\title{
Extracting gDNA Suitable for Molecular Applications from Sugarcane, and its Phytopathogens
}

\author{
Sangeeta Srivastava* and Prashant Shekhar Gupta \\ Crop Improvement Division, ICAR-Indian Institute of Sugarcane Research, \\ Lucknow-226002, India \\ *Corresponding author
}

\section{A B S T R A C T}

\section{Keywords}

gDNA extraction,

Sugarcane,

Phytoplasma, $C$.

falcatum, rRNA

Article Info

Accepted:

20 May 2019

Available Online:

10 June 2019
DNA fingerprinting, estimation of molecular genetic diversity, marker assisted breeding and molecular diagnostic tools are the need of the hour for sugarcane crop improvement. Efficient extraction of genomic DNA (gDNA) free from polysaccharides, polyphenols, RNA and other major contaminants is a key to all these molecular activities. We present herewith, a modified DNA extraction protocol that has been optimized for isolating gDNA from endergonic and hardy sugarcane plant and its phytopathogens and endophytic fungi. The protocol has worked equally well in a number of monocot and dicot plants including rice, maize, linseed, Sesbania, opium poppy, Hyoscyamus, phytoplasma infected sugarcane leaves and smut infected sugarcane whip. The success of this modified protocol was assessed by polymerase chain reaction (PCR)-based amplification and sequencing of amplicons, universality and reliability.

\section{Introduction}

Sugarcane sustains the second largest organized agro-industry in India. About 65\% of sugarcane is cultivated in subtropics while $35 \%$ is in tropics. Sugarcane is most endergonic and hardy crop, grown in almost all the states of the country having diverse agro-climate situations both in tropical and subtropical regions and as such, the problems of sugarcane crop are of distinct and diverse nature. Sugarcane is also known as "Multiutility crop" due to its use as raw material in many industries. Several major diseases caused by various phytopathogens such as phytoplasma (prokaryotes) and fungal pathogens (eukaryotes) adversely affect sugarcane crop growth. These pathogens are responsible for cane yield loss and total crop failure, which may in turn lead to dwindled crop productivity. The various disease epidemics seriously require the attention of pathologists to find out the details about the pathogen and the epidemiology of the disease in order to develop suitable disease management practices. The economically important sugarcane diseases are mostly seed borne like red rot, smut, wilt, leaf scald, ratoon stunting, grassy shoot disease, mosaic etc. Sugarcane grassy shoot (SCGS) 
phytoplasma is associated with ultrastructural changes in chloroplast, chlorophyll, changed orientation of vascular bundles, xylem, sieve tubes and companion cells, hypertrophy, hyperplasia and lignifications of sclerenchymatous cells in leaves.

Breeding for disease resistant varieties is a common practice to manage disease outbreak in sugarcane. The process takes several years and new isolates of pathogens emerge in due course. Marker assisted breeding is essential to cut short the long time span of releasing a resistant variety. Molecular characterization and incipient detection of pathogens on the other hand are essential for disease management and healthy seed cane production. DNA fingerprinting, estimation of molecular genetic diversity, trait linked markers for marker assisted breeding and molecular diagnostic tools are thus the need of the hour for sugarcane crop improvement. Candidate gene identification and sequencing of desired amplicons are the ways to achieve the target, and require high quality genomic DNA (gDNA) that should be free of polysaccharides, polyphenols, RNA and other major contaminants. DNA extraction plays an important role in the field of sugarcane molecular biology as for all such activities, the genomic DNA is the base which should be of high quality and free of major contaminants.

Extracting DNA from leaves of certain plant species (Bramwell et al., 1995; Baker et al., 1990), from conifer wood (De Filipis and Magel 1998; White et al., 2000; Deguilloux et al., 2002), including wild relatives of crop species, and sugarcane has been found to be particularly difficult. Marechal Drouard and Guillemaut (1992) devised protocol to extract DNA from spruce needles and also from mature tree leaves including fir (Abies alba), maple (Acer saccharum), ginkgo (Ginkgo biloba), beech (Fagus sylvatica), date
(Phoenix dactylifera), apple (Malus sylvestris) and peech (Prunus persica), leaves, hypocotyls or dried embryos of bean (Phaseolus vulgaris), leaves or tubers of potato (Solanum tuberosum), leaves of grapevine (Vitis vinifera) and hop (Humulus lupulus), cell suspension cultures or calli, seeds of millets (Setaria italica), barley (Hordeum sativum) and wheat (Triticum aestivum), Lichens and fern (Pteridium aquilinum).

To eliminate contamination problem, several methods have been employed such as sedimentation in cesium chloride gradients or extraction with CTAB and other procedures (Rether et al., 1993; Lodhi et al., 1994; Maguire et al., 1994). However, it is not necessary that these methods are successful in all the crop plants as Porebski et al., (1997) reported unsuccessful attempt to amplify Fragaria DNA by PCR using reported methods such as Dellaporta et al., (1983), Saghai-Maroof et al., (1984), Doyle and Doyle (1992), La Roche (1992), Oard and Dronavalli (1992), Wang et al., (1993), Richards et al., (1994) and Davis et al., (1995), and hence, these methods necessitate modifications as per requirement depending upon the plant species.

Commercial sugarcane cultivars belong to the highly complex heterozygous polyploid genus Saccharum, which is characterized by the high chromosome numbers. Sugarcane tissues are rich in polysaccharides and polyphenolic compounds, which is a major hindrance in the purification of sugarcane genomic DNA. Several DNA extraction protocols have been described for such plants e.g. extaction of nuclei by Hamilton et al., 1972, cesium chloride method by Murray and Thompson 1980, reproducible genomic DNA isolation method by Chiong et al., 2017, rapid DNA extraction from sugarcane by Honeycutt et al., (1992) and Aljanabi et al., (1999), 
microprep protocol for sugarcane by Srivastava and Gupta (2001) and genomic DNA from dry leaf samples of sugarcane by Vaze et al., (2010). Seven rapid protocols of DNA isolation in sugarcane, differing with respect to the composition of extraction buffers and DNA precipitation methods were compared by Srivastava and Gupta 2006 to assess the quantity and quality of genomic DNA extracted from leaf material of different sugarcane genotypes and they suggested some modifications for improvement. Based on the above background, here we present a single modified protocol from Doyle and Doyle 1990, protocol that has been optimized for isolating DNA from the host plant sugarcane (Saccharum spp. hybrid), phytopathogens and endophytic fungi, with properties such as efficient extraction in high quantity of high molecular weight gDNA, its PCR amplifiability and appropriateness for sequencing based applications.

\section{Materials and Methods}

\section{Plant material}

Young, healthy and fast growing leaves of diverse plant species viz. healthy and SCGS phytoplasma infected plants of sugarcane, linseed, rice, maize, Sesbania, Hyoscyamus, Papaver, and mycelial cultures of different fungal isolates on PDA (potato dextrose agar medium) viz. Colletotrichum falcatum, Sporisorium scitamineum, Fusarium moniliforme and Trichoderma viride were taken as experimental material for genomic DNA isolation.

\section{Solutions required}

Extraction Buffer: $200 \mathrm{mM}$ Tris, $\mathrm{pH}$ 7.4, 70 mM EDTA, $0.2 \%$ 2-mercaptoethanol, $2 \mathrm{M}$ $\mathrm{NaCl}, \quad 2 \% \quad \mathrm{CTAB} \quad$ (hexadecyl trimethylammonium bromide), $1 \%$ PVP (polyvinylpyrolidone)
TE buffer: $10 \mathrm{mM}$ Tris pH 8.0, $1 \mathrm{mM}$ EDTA, $\mathrm{pH} 8.0$

SDS Solution: $10 \% \mathrm{w} / \mathrm{v}$

$\mathrm{NaCl}$ Solution: $5 \mathrm{M}$

\section{DNA Extraction Protocol (Step by step)}

Grind $1.0 \mathrm{gm}$ of leaves in liquid nitrogen to fine powder. In case of fungus, harvest the mycelium of fungi grown on PDA medium, with the help of cover slip and grind with liquid nitrogen for DNA extraction.

Transfer the ground material in a small beaker containing $5 \mathrm{ml}$ pre-warmed DNA extraction buffer. Mix it properly.

Add $500 \mu \mathrm{l}$ of $10 \%$ SDS in case of leaves, $750 \mu \mathrm{l}$ of $10 \%$ SDS in phytoplasma infected tissues and $250 \mu \mathrm{l}$ of $10 \%$ SDS in fungal cultures. Mix it properly.

Transfer the mixture in a $20 \mathrm{ml}$ centrifuge tube \& incubate it at $65^{\circ} \mathrm{C}$ in water-bath (Memmert Model 200) for 30-60 min with gentle swirling.

Add equal volume of phenol: chloroform: Isoamyl alcohol (25:24:1). Mix gently to emulsify.

Centrifuge at $8000 \mathrm{rpm}$ in high speed cold centrifuge (Biofuge Stratos) for $15 \mathrm{~min}$ at $10^{\circ} \mathrm{C}$.

Transfer the aqueous phase containing DNA with a wide-bore pipette to an autoclaved new centrifuge tube.

Add equal volume of chloroform: Isoamyl alcohol (24:1). Mix gently to emulsify.

Centrifuge at $8000 \mathrm{rpm}$ in high speed cold centrifuge (Biofuge Stratos) for $15 \mathrm{~min}$ at $10^{\circ} \mathrm{C}$. 
Transfer the aqueous phase containing DNA with a wide-bore pipette to an autoclaved new centrifuge tube.

Add 0.6 volume of cold isopropanol and mix gently to precipitate the DNA.

Spool out DNA with a glass hook if large strands of DNA appear. Otherwise centrifuge at $8000 \mathrm{rpm}$ for $5 \mathrm{~min}$.

Gently pour off the supernatant and wash the DNA pellet in chilled $70 \%$ ethanol for 20 $\min$.

Centrifuge again at $8000 \mathrm{rpm}$ for $10 \mathrm{~min} \&$ discard the solution.

Dry the pellets and dissolve in $500 \mu \mathrm{TE}$ buffer. Here is your crude DNA sample. RNA, protein and polysaccharides are major constituents in crude DNA extraction. Degraded protein, polysaccharides and cell debris are removed during extraction of chloroform: isoamyl alcohol. The RNA is removed by treating the dissolved DNA with RNase in following steps.

Add $5 \mu \mathrm{l}$ of boiled RNase $(10 \mathrm{mg} / \mathrm{ml})$ to crude DNA sample and incubate at $37^{\circ} \mathrm{C}$ for one hour.

Add equal volume of phenol: chloroform: Isoamyl alcohol (25:24:1) and mix gently.

Centrifuge at $8000 \mathrm{rpm}$ for $15 \mathrm{~min}$ at $10^{\circ} \mathrm{C}$. Pipette out aqueous phase in a fresh autoclaved centrifuge tube.

Extract again with chloroform: Isoamyl alcohol (24:1). Centrifuge at $8000 \mathrm{rpm}$ and pipette out aqueous phase in fresh tube.

Add $5 \mathrm{M} \mathrm{NaCl}$ to a final concentration of 0.2 M \& equal volume of $100 \%$ chilled ethanol to precipitate pure DNA.
Centrifuge at $10,000 \mathrm{rpm}$ for $5 \mathrm{~min}$ at $4^{\circ} \mathrm{C}$. Rinse the DNA pellets with $70 \% \mathrm{v} / \mathrm{v}$ ethanol and allow air-drying up to $30 \mathrm{~min}$.

Resuspend the pellets in TE buffer.

\section{Checking quality and quantity of DNA}

The purified DNA was visualized in $1 \%$ agarose gel stained with ethidium bromide to check its purity and to estimate its quantity. The molecular weight of isolated DNA was $\sim 20 \mathrm{~Kb}$ and uniform concentration of $5 \mathrm{ng} / \mu \mathrm{l}$ was standardized for the polymerase reaction. Aliquots of DNA in a uniform concentration of $5 \mathrm{ng} / \mu \mathrm{l}$ were prepared and DNA was kept at $4^{\circ} \mathrm{C}$ until further use and then stored at $20^{\circ} \mathrm{C}$. DNA was kept at $4^{\circ} \mathrm{C}$ until use and then stored at $-20^{\circ} \mathrm{C}$.

\section{PCR Amplification of genomic DNA}

The genomic DNA (gDNA) templates of sugarcane, fungal pathogens viz. Sporisorium, Colletotrichum, Fusarium and endophytic fungus Trichoderma were amplified by PCR using universal oligonucleotides ITS 4 (5'TCC TCC GCT TAT TGA TAT GC - 3') and ITS 5 (5'- GGA AGT AAA AGT CGT AAC AAG G - 3') (White et al., 1990) to amplify nuclear rRNA gene fragment containing ITS1, ITS2 and the 5.8S rRNA gene. Oligonucleotide primers P4 (5'- GAA GTC TGC AAC TCG ACT TC- 3') and P7 (5'CGT CCT TCA TCG GCT CTT- 3') were used to prime the amplification of $16 \mathrm{~S}$ and 23S rDNA sequences from phytoplasma infected leaves. PCR amplification reactions were performed in a total volume of $50 \mu 1$. Each reaction mixture contained 10 to $100 \mathrm{ng}$ of template DNA, $2 \mathrm{mM} \mathrm{MgCl} 2,20$ pmol of each primer, $200 \mathrm{mM}$ of each $\mathrm{dNTP}$, and $2 \mathrm{U}$ of DNA polymerase (Thermo) in a reaction buffer containing $75 \mathrm{mM}$ Tris $\mathrm{HCl}(\mathrm{pH} 9.0)$, $50 \mathrm{mM} \mathrm{KCl}, 20 \mathrm{mM}(\mathrm{NH} 4)_{2} \mathrm{SO}_{4}$, and $0.001 \%$ BSA. The polymerase chain reaction was 
carried out in a MJ PTC 200 Thermal Cycler (BioRad, U.S.A.) programmed to perform a initial denaturation step of $95^{\circ} \mathrm{C}$ for $5 \mathrm{~min}$, followed by 35 cycles consisting of $30 \mathrm{~s}$ at $95^{\circ} \mathrm{C}$ for denaturation, $30 \mathrm{~s}$ at $55^{\circ} \mathrm{C}$ for annealing, and $1 \mathrm{~min}$ at $72^{\circ} \mathrm{C}$ for extension with $10 \mathrm{~min}$ elongation at $72^{\circ} \mathrm{C}$ with final cooling at $4^{\circ} \mathrm{C}$ for $15 \mathrm{~min}$. PCR products were loaded in a $2.0 \%$ agarose gel containing 1 $\mathrm{mg} / \mathrm{ml}$ ethidium bromide in TAE buffer.

Electrophoretic separation was performed in BioRad SubCell GT electrophoresis unit at 80 $\mathrm{V}$ for $30 \mathrm{~min}$. The resulting DNA fragments were visualized by UV trans-illumination and analyzed using AlphaImager ${ }^{\mathrm{TM}}$ Gel Documentation System (Protein Simple, USA).

\section{Clean-Up and sequencing of PCR Products}

Desired PCR products were purified with Ultrafree DA Gel Extraction Kit, MILLIPORE, USA and got sequenced using an automated DNA sequencer ABI 3100. Annotated sequences were submitted to Genbank. A sequence homology search for each product was conducted through Internet Database programme BLASTn algorithm (www.embl.ac./uk).

\section{Results and Discussion}

Purified DNA has been obtained from sugarcane and its phytopathogens following this efficient and universal procedure. This method was further applied to some other crops to check its efficiency and universality, and was found suitable for linseed, rice, maize, Sesbania, Hyoscyamus and Papaver too. The ITS4 and ITS5 primer pairs were used to amplify the ribosomal region containing noncoding and 5.8S rRNA gene, in Saccharum hybrid cultivar CoLk 8102 and fungal isolates of diverse strains belonging to $C$. falcatum (Cf07) causing red rot disease, $S$. scitamineum (cv. CoSe 92423) causing smut, $F$. moniliforme (Fm01) causing wilt, and $T$. viride (Tv01) - an endophytic fungi. The PCR products showed a single amplicon of $\sim 600$ bp in Saccharum spp. hybrid cv. CoLk 8102 (Figure 1a) \& other fungi (Figure 1b). An amplicon of $\sim 500 \mathrm{bp}$ was obtained in grassy shoot disease (SCGS) affected leaves using primer pairs P4 \& P7 which amplified 23S rRNA \& spacer region of phytoplasma (Figure 1c). Desired PCR products were purified and sequenced using an automated DNA sequencer ABI 3100. Bioinformatics analysis conducted through BLASTn program to hit upon homology search representing reasonable $\mathrm{E}$ value and Score is given in Table 1.

Annotated sequences of Saccharum hybrid CoLk 8102, Colletotrichum falcatum pathotype $\mathrm{Cf}$ 07, Fusarium moniliforme isolate Fm 01, Trichoderma viride isolate Tv 01, Sporisorium scitamineum isolate CoSe 92423 and SCGS phytoplasma from var. CoLk 8102 were submitted directly to GenBank through WEBIN and SAKURA (a World Wide Web sequence submission servers available at EMBL and DDBJ). The sequences are available on line and can be located by accession numbers AJ880278, AB242410, AF333333, AT444444, AB246362 and AM085764.

Various plants contain high levels of polysaccharides and many types of secondary metabolites that affect DNA purification. Certain polysaccharides and secondary metabolites such as polyphenols, terpenoids and resins are known to inhibit PCR reactions (Pandey et al., 1996). To overcome these problems, several methods have been employed. The current study is also a part on this line. The sugarcane plant tissues are in general a difficult material for DNA isolation due to the presence of various secondary plant products as polyphenols and polysaccharides. 
Fig.1 Genomic DNA amplification of rDNA. (a) ITS region of Saccharum hybrid cultivar CoLk 8102, (b) ITS region of pathogenic and endophytic fungi, and (c) 16S-23S rRNA region of phytoplasma DNA in SCGS disease affected Saccharum hybrid cultivar CoLk 8102

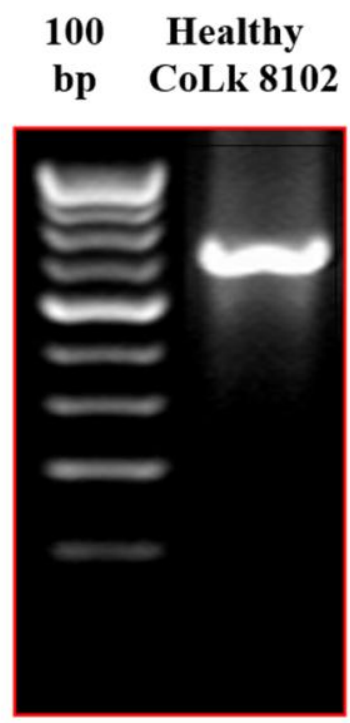

(a)

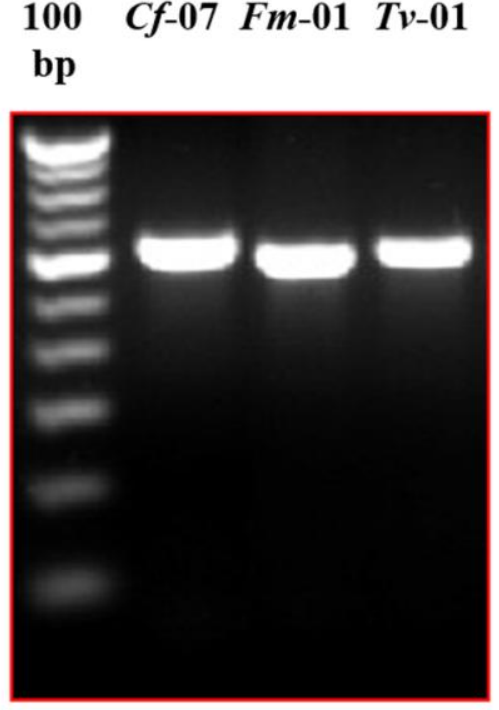

(b)
100 SCGS infected bp CoLk8102

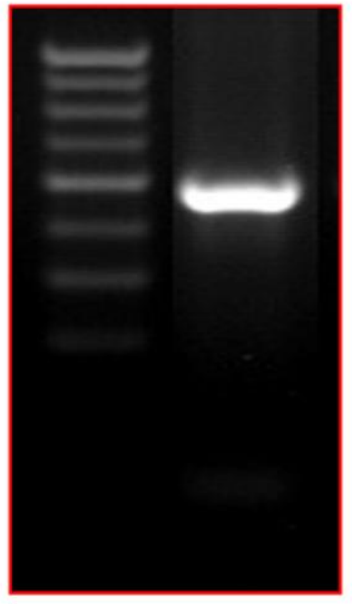

(c)

Table.1 Sequence homology search and comparison of rDNA sequences from sugarcane and its phytopathogens with GenBank database

\begin{tabular}{|c|c|c|c|c|c|}
\hline & & $\begin{array}{c}\text { GenBank } \\
\text { Accession } \\
\text { no. }\end{array}$ & $\begin{array}{l}\text { GenBank } \\
\text { Accession } \\
\text { no. }\end{array}$ & $\begin{array}{c}\text { GenBank } \\
\text { Accession } \\
\text { no. }\end{array}$ & $\begin{array}{c}\text { GenBank } \\
\text { Accession } \\
\text { no. }\end{array}$ \\
\hline \multirow{3}{*}{$\begin{array}{l}\text { Saccharum spp. hybrid } \\
\text { CoLk 8102 } \\
\text { (AJ880278) }\end{array}$} & & (AF345226) & (AF345223) & (AF345224) & (AF345239) \\
\hline & Score & 1112 & 1112 & 1112 & 1096 \\
\hline & E value & 0.0 & 0.0 & 0.0 & 0.0 \\
\hline \multirow{3}{*}{$\begin{array}{l}\text { Red rot pathogen } \\
\text { Cf 07 } \\
\text { (AJ876759) }\end{array}$} & & (AY944753) & (AY944748) & (AY944747) & (AY944743) \\
\hline & Score & 1031 & 1031 & 1031 & 1017 \\
\hline & E value & 0.0 & 0.0 & 0.0 & 0.0 \\
\hline \multirow{3}{*}{$\begin{array}{l}\text { Wilt pathogen } \\
\text { Fm 01 } \\
\text { (AF333333) }\end{array}$} & & (AF455450) & (AY533376) & (AF158314) & (AF158313) \\
\hline & Score & 1017 & 1017 & 1013 & 1013 \\
\hline & E value & 0.0 & 0.0 & 0.0 & 0.0 \\
\hline \multirow{3}{*}{$\begin{array}{l}\text { Endophytic fungi } \\
\text { Tv 01 } \\
\text { (AT444444) }\end{array}$} & & (AF510496) & (AB194281) & (DQ200258) & (AF176660) \\
\hline & Score & 1013 & 1009 & 1005 & 995 \\
\hline & E value & 0.0 & 0.0 & 0.0 & 0.0 \\
\hline \multirow{3}{*}{$\begin{array}{l}\text { Smut pathogen } \\
\text { S. scitamineum-92423 } \\
\text { (AB246362) }\end{array}$} & & (AY345007) & (DQ004831) & (DQ004829) & (AF135433) \\
\hline & Score & 301 & 272 & 258 & 256 \\
\hline & E value & $5 e-79$ & $5 e-70$ & $7 e-66$ & $3 e-65$ \\
\hline \multirow{3}{*}{$\begin{array}{l}\text { SCGS Phytoplasma } \\
\text { CoLk 8102 } \\
\text { (AM085764\} }\end{array}$} & & (DQ380345) & (DQ380344) & (DQ380341) & (DQ380340) \\
\hline & Score & 361 & 361 & 361 & 361 \\
\hline & E value & $1 e-96$ & $1 e-96$ & $1 e-96$ & $1 e-96$ \\
\hline
\end{tabular}


The protocols available in literature were used for DNA extraction using reported methods, including those of Dellaporta et al., 1983, Maroof et al., 1984, Oard and Dronovalli 1992, Wang et al., 1993. However, as the results of a single protocol were not suitable for host tissue as well as pathogens, we found it necessary to devise a single and simple cost effective protocol for DNA extraction from leaves of sugarcane and their phytopathogens. As the phytoplasma is present in hard midrib of sugarcane leaves, the protocol described here was relatively quick, inexpensive and effective for phytoplasma as well. The quality of DNA isolated by this method was evaluated by performing universal PCR-based applications. The yield of pure DNA obtained through current protocol ranged from 20-160 $\mu \mathrm{g} / \mathrm{gm}$ of material with $\mathrm{A}^{260} / \mathrm{A}^{280}$ ratios in the range of 1.8 to 1.95 and the DNA is easily able to amplify as tested by rRNA region amplification and their sequencing. There is no visible contamination of RNA in electrophoresed gel. This method was evaluated for universality, speed, and reliability using PCR based applications. It was found suitable for both small and large scale extraction. RFLP analysis, cloning, creation of gene banks and various other techniques are also sensitive to DNA quality.

We have presented here a modified protocol of Doyle and Doyle 1990 as described above that has worked equally well in a number of plants including sugarcane, rice, maize, linseed, Sesbania, opium poppy, Hyoscyamus as well as phytoplasma infected sugarcane leaves, smut infected sugarcane whip and mycelial cultures of different strains belonging to red rot pathogen $C$. falcatum, wilt pathogen $F$. moniliforme, smut pathogen S. scitamineum and endophytic fungi $T$. viride. In short, this modified procedure is able to efficiently produce purified gDNA from sugarcane, its phytopathogens as well as diverse monocot and dicot plant species that is suitable for PCR based applications as well as for sequencing purposes.

\section{Acknowledgements}

The authors are highly grateful to The Director, IISR, Lucknow, for providing the necessary facilities to carry out the experiments. Financial assistance from DBT to PSG in the form of fellowship is gratefully acknowledged.

\section{References}

Aljanabi, S.M., Forget, L. and Dookun, A. 1999. An improved and rapid protocol for the isolation of polysaccharide- and polyphenol-free sugarcane DNA. Plant Mol. Biol. Reptr. 17: 1-8.

Bramwell, P.A., Barallon, R.V., Rogers, H.J., and Bailey, M.J. 1995. Extraction of microbial DNA from the phylloplane. In: Akkermans, A.D.L., Van Elsas, J.D, and De Bruijin, F.J., (Eds.) Molecular Microbial Ecology Manual, Springer, Dordrecht pp. 109-129.

Baker, S.S., Rugh, C.L., and Kamalay, J.C. 1990. RNA and DNA isolation from recalcitrant plant tissues. Bio Techniques. 9:268: 272.

Chiong K.T., Damaj M.B., Padilla C.S., Avila C.A., Pant S.R., Mandadi K.K., Ramos N.R., Carvalho D.V. and Mirkov, T.E. 2017. Reproducible genomic DNA preparation from diverse crop species for molecular genetic applications. Plant Methods

13:106 https://doi.org/10.1186/s13007-0170255-6

Davis, T.M., Yu, H., and Haigis, K.M., and McGowan, P.J. 1995. Template mixing: A method of enhancing detection and interpretation of codominant RAPD markers. Theor. Appl. Genet. 91:582586.

De Filipis, L., and Magel, E. 1998. 
Differences in genomic DNA extracted from bark and from wood of different zones in Robina trees using RAPDPCR. Trees. 12: 277-384.

Deguilloux, M.F., Pemonge, M.H., and Petit, R.J. 2002. Novel perspectives in wood certification and forensics: dry wood as a source of DNA. Proc R Soc Lond Ser B-Biol Sci. 269: 1039-1046.

Dellaporta, S.L., Wood, J., and Hicks, J.B. 1983. A plant DNA mini preparation: Version II. Plant Mol. Biol. Rep. 1: 1921.

Doyle, J.J., and Doyle, J.L. 1990. Isolation of plant DNA from fresh tissue. Focus. 12: 13-15.

Guillemaut, P., and Marechal-Drouard, L. 1992. Isolation of plant DNA: A fast, inexpensive and reliable method. Plant Mol. Biol. Rep. 10: 60-65.

Hamilton, R.H., Künsch, U. and Temperli, A. 1972. Simple rapid procedures for isolation of tobacco leaf nuclei. Analyt. Biochem. 49: 48-57.

Honeycutt, R.J., Sobral, B.W.S., Kiem, P. and Irvine, J. 1992. A rapid DNA extraction method for sugarcane and its relatives. Plant Mol. Biol. Reptr. 10: 66-72.

La Roche, J. 1992. An easy and efficient procedure for isolating plant DNA using the Elu-Quick DNA purification kit. Sequences. 36: 3-4.

Lodhi, M.A., Ye, G.N., Weeden, N.F., Reisch, B.I. 1994. A simple and efficient method for DNA extractions from grapevine cultivars and Vitis species. Plant Mol. Biol. Rept. 12:6-13.

Maguire, T.L., Collins, G.G., and Margaret S. 1994. A modified CTAB DNA extraction procedure for plants belonging to the family proteaceae. Plant Molecular Biology Reporter. 12(2): 106-109.

Mare'chal-Drouard, L. and Guillemaut, P. 1995. A powerful but simple technique to prepare polysaccharide-free DNA quickly and without phenol extraction. Plant Mol. Biol. Reptr. 15: 26-30.

Murray, M.G. and Thompson, W.F. 1980. Rapid isolation of high molecular weight plant DNA. Nucleic Acids Res. 8: 4321-4325.

Oard, J.H., and Dronavalli, S. 1992. Rapid isolation of rice and maize DNA for analysis by random-primer PCR. Plant Mol. Biol. Rept. 10:236-241.

Pandey, R.N., Adams, R.P., and Flournoy, L. E. 1996. Inhibition of random amplified polymorphic DNAs (RAPDs) by plant polysaccharides. Plant Mol. Biol. Rep. 14(1):17-22.

Porebski, S., Bailey, L.G., Baum, B.R. 1997. Modification of a CTAB DNA extraction protocol for plants containing high polysaccharide and polyphenol components. Plant Mol Biol Rep. 15: 815.

Rether, B., Delmas, G., and Laouedj, A. 1993. Isolation of polysaccharides-free DNA from plants. Plant Mol. Biol. Reptr. 11: 333-337.

Richards, E., Reichardt, M., and Rogers, S. 1994. Preparation of genomic DNA from plant tissue. In: Ausubel, F.M., Brent, R., Kingston, R.E., Moore, D.D., Seidman, J.G., Smith, J.A., and Struhl, K. (Eds.). Current Protocols in Molecular Biology, New York: Wiley. 27(1): 231-237.

Saghai-Maroof, M.A., Soliman, K.M., Jorgensen, R. A., and Allard, R.W. 1984. Ribosomal DNA spacer length polymorphism in barley: Mendelian inheritance, chromosomal location, and population dynamics. Proc. Natl. Acad. Sci. USA. 81:8014:8019.

Srivastava, S., and Gupta, P.S. 2001. Microprep protocol for DNA isolation from sugarcane. Ind. J. of Sugarcane Technology. 16: 88-90.

Srivastava, S., and Gupta, P.S. 2006. Assessment of small-scale methods for 
quick extraction of genomic DNA from leaf tissue of sugarcane. Cytologia. 71: 181-188.

Vaze, A., Nerkar, G., Pagariya, M., Devarumath R.M., and Theertha Prasad. D. 2010. Isolation and PCR amplification of genomic DNA from dry leaf samples of sugarcane. International Journal of Pharma and Bio
Sciences V1 (2): 1-6.

White, T.J., Bruns T.D., Lee, S.B., Taylor, J.W., Innis, M.A., Gelfand, D.H., and Sninsky J. 1990. Amplification and Direct Sequencing of Fungal Ribosomal RNA Genes for Phylogenetics. In: PCR Protocols. A guide to methods and applications. Publisher: Academic Press, Inc. pp. 315-322.

\section{How to cite this article:}

Sangeeta Srivastava and Prashant Shekhar Gupta. 2019. Extracting gDNA Suitable for Molecular Applications from Sugarcane, and its Phytopathogens. Int.J.Curr.Microbiol.App.Sci. 8(06): 2670-2678. doi: https://doi.org/10.20546/ijcmas.2019.806.321 